\title{
ANALISA SEMIOTIKA VISUAL FILM BULAN TERBELAH DI LANGIT AMERIKA
}

\author{
Rizki Rengganu Suri Perdana \\ Universitas Diponegoro \\ rizki.rengganu04@gmail.com
}

\begin{abstract}
Abstrak
Terorisme didefinisikan sebagai sebuah doktrin yang mengandung unsur intimidasi, kekerasan dan brutalisme melawan warga sipil sebagai dasar dengan motivasi tertentu. Dalam beberapa tahun terakhir, beberapa pembuat film telah mengangkat persoalan yang terjadi dalam masyarakat untuk membangun perhatian tentang isu terkait,salah satunya adalah film Bulan Terbelah di Langit Amerika. Metode yang dipakai dalam penelitian ini adalah Metode Analisis Semiotik film (MAS) Christian Metz.Bahasa struktur film kemudian dibagi menjadi delapan pengelompokan dalam "The Large Syntagmatic Category" .Teori yang digunakan adalah Sigmund Freud - Psikoanalisis, yaitu untuk melihat bagaimana representasi dari karakter yang dibentuk dari hasil tabarakan montage,dan Sergei Eisenstein - Teori Montage,adalah teori yang digunakan untuk memunculkan serta menimbulkan emosi kepada audience. Hasil dari penelitian ini: (1) Teror, direpresentasikan berupa penekanan akan Super Ego pada karakter, (2) Intimidasi, direpresentasikan melalui media-media menyorot karakter Sarah dan Azima, sehingga menciptakan trauma psikologis kepada mereka, terlihat kekerasan simbolik yang terlihat dari narasi (verbal) dan bahasa tubuh (non verbal), (3) Pengakuan Bangsa Barat, direpresentasikan melalui karakter Philipus Brown dan bentuk dorongan Id nya yang akhirnya membuat keseluruhan karakter memiliki kesamaan Id
\end{abstract}

Kata Kunci : Bulan Terbelah di Langit Amerika, Semiotik, Film Teroris

\begin{abstract}
Terrorism is defined as a doctrine that contains elements of intimidation, violence and brutality against civilians as a basis with certain motivations. In recent years, some filmmakers have raised the issues that occur in society to build attention to related issues, one of which is the film of Bulan Terbelah di Langit Amerika. The method used in this study is the Semiotic Analysis Film Method (MAS) Christian Metz.The structure of the film is then divided into eight groupings in "The Large Syntagmatic Category". The theory the author uses is Sigmund Freud - Psychoanalysis, the theory is to see how the representation of the characters formed from the results of montage, and Sergei Eisenstein - Montage Theory, is a theory used to generate emotion to the audience. The results of this study (1) Terror, represented in the form of Super Ego emphasis on the character (2) Intimidation, represented through the media highlighted the character of Sarah and Azima, thus creating psychological trauma to them, seen symbolic violence seen from the narrative (verbal) and body language (non verbal), (3) Confession of the West, represented by the character of Philipus Brown and the form of his Id impulse that eventually made it whole an character has a similarity Id.
\end{abstract}

Kata Kunci : Bulan Terbelah di Langit Amerika, Semiotics, Terrorism Movie. 


\section{Pendahuluan}

Pasca terjadinya tragedi 11 September, para penganut agama Islam yang tinggal di Amerika mengalami kekerasan secara fisik ataupun non fisik. Sebuah laporan yang diterbitkan pada Mei 2016 oleh Bridge Initiative, sebuah proyek penelitian di Universitas Georgetown, menemukan bahwa umat Islam antara enam hingga sembilan kali lebih banyak diserang pada tahun 2015, dibandingkan periode setelah serangan 11 September 2001. Laporan ini mendokumentasikan, sekitar 180 insiden kekerasan anti-Muslim terjadi sejak dari waktu pencalonan presiden diumumkan pertama kali pada Maret 2015 hingga Mei tahun ini, termasuk 12 pembunuhan dan 34 serangan fisik ( www.mirajnews.com/id/muslim- as-terancam - oleh- Islamofobia/125824 ).

Sejak serangan terror yang mengguncang Amerika dan dunia, banyak orang Amerika yang cemas jika berpikir mengenai Islam, hal tersebut karena media kian kali menyoroti aksi terorisme yang terjadi di dunia dengan memberitakan dan mengaitkan hal tersebut dengan agama Islam. Sebagaimana yang dikatakan Pasca tragedi 11 September, muslim Amerika Serikat menjadi objek diskriminasi, perlakuan yang tidak baik, kekerasan fisik maupun mental di dalam negaranya sendiri (PEW Research Center, 2011). Tragedi tersebut benar-benar memberikan perubahan pada kebijakan pemerintah, media massa, pendidikan, bahkan budaya masyarakat Amerika Serikat. Sebagai hasilnya, muslim Amerika Serikat mengalami 'penahanan', mendapat julukan rasial 'teroris', mendapatkan kekerasaan dalam kehidupannya sehari-hari, diskriminasi, perlakukan buruk baik fisik maupun mental dari komunitas lokal maupun masyarakat Amerika Serikat. Perlakuan buruk dan diskriminasi terhadap muslim di Amerika Serikat lebih dominan dialami oleh perempuan muslim terutama mereka yang menggunakan hijab. Hijab dinilai sebagai simbol Islam.

Pasca tragedi tersebut, Islam dinilai sebagai agama teroris sehingga perempuan muslim dianggap sebagai bagian dari teroris. Equal Employment Opportunity Commission (EEOC) melaporkan bahwa telah terjadi peningkatan diskriminasi di tempat kerja sejak tahun 20012006 mencapai hampir 11.000 kasus (Malos, 2009). Peningkatan diskriminasi di tempat kerja terhadap muslim meningkat dua kali lipat pada tahun 2005 (Intan Sari, Diah Ayu: Diskriminasi Perempuan Muslim dalam Implementasi Civil Right Act 1964 di Amerika Serikat )

Kemudian 66\% warga Amerika menolak pembangunan pusat aktivitas Muslim, dua blok dari Ground Zero. Demikian hasil jajak pendapat "Washington Post". Tidak masalah bahwa di jalan yang sama terdapat klub tari telanjang dan bar, tempat minum-minum, karena hal itu tak ada hubungannya dengan teroris yang menghancurkan World Trade Center. Maka timbulah stigma di masyarakat Amerika (non Muslim) bahwa orang-orang berjenggot, bergamis, bercelana di atas mata kaki, wanita berjilbab berarti adalah teroris dan mereka mendapatkan perlakuan yang tidak adil. Mulai dari pelecehan hingga kekerasan. Hal tersebut mengakibatkan sebagian dari mereka (Muslim) melepas jilbabnya dan mencukur jenggotnya agar mereka tidak dikenali identitasnya sebagai seorang Muslim, hal tersebut dilakukan agar mereka tidak mendapatkan perlakuan-perlakuan yang tidak adil.

Beberapa tahun ini, para pembuat film menampilkan film yang mengangkat fenomena dan isu - isu sosial yang terjadi di masyarakat untuk menarik perhatian masyarakat dan 
meningkatkan nilai pasaran. Salah satunya Bulan Terbelah di Langit Amerika menawarkan kepada kita tentang cerita dari beberapa sudut pandang pasangan, ada pasangan suami istri dan anak yang beragama Islam dan suaminya yang meninggal saat peristiwa 9 / 11, pasangan suami istri yang istrinya menjadi korban dalam peristiwa 9 / 11 , kemudian pasangan suami istri yang tengah menjalankan studi S3-nya disana, dan pekerjaan disana, serta seorang ayah dan anak, yang dimana menjadi seorang saksi pada peristiwa 9 / 11. Hanum Salsabiela dan Rangga Almahendra penulis skenario dan buku membuat kejutan luar biasa setelah sukses dengan film dan buku 99 langit di eropa kini mereka menjadikan kembali karya novel Bulan Terbelah di Langit Amerika menjadi film layar lebar. Kata bulan terbelah pada judul film ini merupakan repesentasi dari terbelahnya masyarakat Amerika yang menjadi muslim dan non muslim pasca terjadi peristiwa 9 / 11 dimana pada peristiwa tersebut menewaskan hampir 3000 orang. Sebagai film sekuel dari film 99 Cahaya di Langit Eropa yang sukses, film yang mengadapatasi novel best seller dengan judul yang sama. Bulan terbelah di langit eropa mengangkat isu global yang sensitif tentang pandangan masyarakat dunia terhadap Islam, serta bagaimana Amerika memandang Islam pasca terjadi nya 9 / 11 di Amerika karena selama ini jika terjadi kasus terorisme maka akan selalu dikaitkan dengan Islam yang menjadi dalangnya, tetapi sebenarnya Islam juga dirugikan.

\section{Tujuan Penelitian}

Adapun tujuan penelitian dari penelitian ini adalah bagaimana terorisme di representasikan dalam film "Bulan Terbelah di Langit Amerika."

\section{Kerangka Teori}

Pendekatan semiotika atau ilmu tanda mengandaikan serangkaian asumsi dan konsep yang memungkinkan kita untuk menganalisis sistem simbolik dengan cara sistemastis. Linguis asal Swiss. Ferdinand De Saussure merupakan pelopor ilmu ini (Culler, 1977). Semiotika mengambil model awal dari bahasa verbal, bahasa verbal hanyalah satu dari sekian banyak sistem tanda yang ada dimuka bumi. Tanda adalah sesuatu yang merepresentasikan atau menggambarkan sesuatu yang lain. Tanda terdiri atas dua materi dasar yakni ' ekpresi ' ( seperti kata, suara, atau symbol dan sebagainya ) dan "konten" atau "isi" (makna atau arti) (Hjemlev,1961). Proses penghubungan atau pemaknaan ekpresi dengan konten bersifat sosial dan sangat bergantung pada perspektif atau cara berfikir sang pengamat. Tanda tidak pernah sepenuhnya "lengkap" karena memerlukan "interpretan" atau konteks. Dengan demikian, hanya kontekslah yang dapat menghubungkan ekpresi dengan konten. Ketika interpretan berubah, konten atau makna otomatis berubah. Semiotika mempelajari apa saja yang dianggao sebagai tanda dan menolak tanda yang bersifat 'absolut'.Singkat kata, interpretan sebuah tanda adalah tanda lain, sebuah tanda dapat di uji validitas atau kebenarannya hanya dengan tanda lain, begitu seterusnya tanpa mengadaikan suatu akhir yang definitf.

Fungsi tanda di dalam analisis sosial sangat penting artinya karena tandalah yang menghadirkan kekhususan dan mendukung relasi - relasi sosial di tengah - tengah masyarakat. 
Pada segi - segi tertentu, kekayaan makna pada suatu tanda sering kali tereduksi oleh pengetahuan, aturan, dan kode - kode yang diakai oleh konvensi budaya tertenu. Pemahaman tanda memerlukan pengetahuan yang tidak sedikit ( Giddens,1984) karena tanda kerap diabaikan atau bahkan sama sekali tidak dikenali oleh orang - orang yang menerapkannya

\section{a. Sigmund Freud - Psikoanalisis}

Film berpusat pada sebuat cerita yang digambarkan oleh sebuah tokoh, baik itu tokoh utama dalam film tersebut ataupun tokoh tambahan yang membantu tokoh utama dalam sebuat plot cerita, sehingga sifat serta ciri yang melekat pada mereka membuat menjadi keunikan tersendiri dalam film, dan sebuah konflik yang terjadi dalam film digerakan oleh tokoh yang dibuat oleh sutradara film tersebut, peneliti menggunakan Teori Psikoanalisis Sigmund Freud untuk membedah bagaimana representasi tokoh dalam film Bulan Terbelah di Langit Amerikabaik itu karakter, sifat yang terdapat dalam penokohannya, sebagaimana yang di katakana oleh Sigmund Freud (Psikologi film, 2010 ), terdapat tiga kunci yait Id, Ego, dan Super Ego : teori ini digunakan oleh peneliti untuk membedah gagasan dari sutradara melalui perilaku verbal dan non verbal dari para aktor

- Id : Id berisikan motifasi dan energy positif dasar, yang sering disebut insting atau stimulus. Id berorientasi pada prinsip kesenangan (pleasure principle) atau prinsip reduksi ketegangan, yang merupak sumber dari dorongan-dorongan biologis (makan, minum, tidur, dll) Prinsip kesenangan merujuk pada pencapaian kepuasan yang segera, dan id orientasinya bersifat fantasi (maya).

- Ego : Peran utama dari ego adalah sebagai mediator (perantara) atau yang menjembatani anatar id dengan kondisi lingkungan atau dunia luar dan berorintasi pada prinsip realita (reality principle). Dalam mencapai kepuasan ego berdasar pada proses sekunder yaitu berfikir realistis dan berfikir rasional. Dalam proses disebelumnya yaitu proses primer hanya membawanya pada suatu titik, di mana ia mendapat gambaran dari benda yang akan memuaskan keinginannya, langkah selanjutnya adalah mewujudkan apa yang ada di das es dan langkah ini melalui proses sekunder. Dalam upaya memuaskan dorongan, ego sering bersifat prakmatis, kurang memperhatikan nilai/norma, atau bersifat hedonis.

- Super Ego : Super ego merupakan moril atau keadilan dari kepridadian, yang mewakili alam ideal daripada alam nyata serta menuju kearah yang sempurna yang merupakan komponen kepribadian terkait dengan sytandar atau norma masyarakat mengenai baik dan buruk, benar dan salah.

\section{b. Teori Montage-Sergei Einseistein}

Montase adalah prinsip suatu organisasi dari elemen film yang diatur, yaitu ada visual dan audio atau kombinasi dari keduanya, kedua elemen tersebut disejajarkan, digabungkan atau dikontrol durasinya (Aumont, 1992: 45). Montase Sergei Eisenstein disebut dengan atraksi montase. Hal ini dikarenakan Sergei Eisenstein melakukan pendekatan teater dan pendekatan tersebut mempengaruhi teorinya. 
Baginya, pendekatan teater memilik keterkaitan dengan film. Teori montasenya disebut dengan atraksi montase. Tahun 1923, sebuah artikel yang diterbitkan dalam Jurnal Lef diedit oleh Vladimir Mayakovsky. Sergei Eisenstein menyatakan bahwa istilah 'bahan dasar' teater 'berasal dari penonton' dan dia memberikan definisinya sebagai atraksi montase. Setiap saat ada momen agresif dalam teater, yaitu setiap elemen itu mempengaruhi subyek penonton baik secara emosional maupun psikologis, berdasarkan pengalaman dan perhitungan matematis untuk menghasilkan guncangan emosional tertentu dalam penonton. These memberikan satu-satunya kesempatan mempersepsi aspek ideologis dari apa yang ditunjukkan, konklusi ideologi akhir.

Sergei Eisenstein menyatakan, frame menjadi batasan dari gambar dan digambarkan objek yang berdiri di dalam sebuah produktifitas ketegangan pada masing-masing gambar yang lain. Posisi dari kamera menghadirkan kembali materi dari konflik antara pembentukan logika sutradara dengan logika dari fenomena tabrakan, membentuk dialektika dari angle kamera (Elsaesser \& Hagener, 2010:23). Selain itu, Sergei Eisenstein juga menganggap bahwa shot seperti sebuah sel yang hidup dalam kehidupan organisme. Sel merupakan individu yang mandiri tetapi sel tetap harus memenuhi fungsi tertentu sebagai sebuah sel di dalam satu kesatuan organisme yang lebih besar. Artinya shot tidak memiliki makna di dalam elemen montase (Elsaesser \& Hagener, 2010:25).Sergei Eisenstein menyebutkan bahwa montase adalah konflik. Jika Shot A ditabrakkan dengan Shot B maka akan menghasilkan Shot AB sebagai hasil konflik.
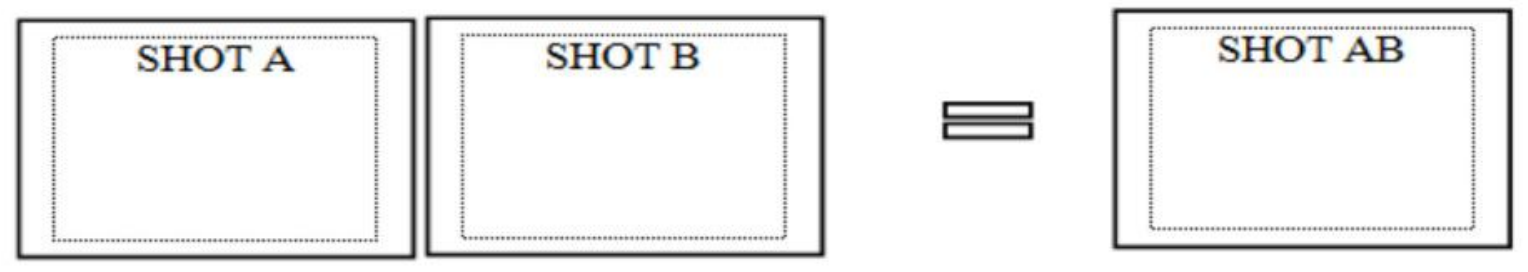

Dari pernyataan Sergei Eisenstein di atas dapat diketahui bahwa terdapat batasan sebuah gambar. Masing-masing frame memiliki ketegangan sendiri yang dipengaruhi oleh posisi kamera. Posisi kamera dengan frame memiliki konflik. Sehingga, fenomena tabrakkan antara shot A dan shot B membentuk dialektika dari angle kamera. Selain itu, montase tidak dapat berdiri sendiri dalam film. Artinya, montase tidak memiliki makna dalam film jika berdiri sendiri. Hal ini disebabkan montase seperti sebuah sel seperti yang telah disebutkan Sergei Eisenstein di atas.

\section{Metode Penelitian}

Penelitian ini merupakatan tipe penelitian kualititatif. Penelitian kualitatif bertujuan untuk memahami situasi, peristiwa, kelompok atau interaksi sosial tertentu dan peneliti kualitatif juga tidak mempunyai seperangkat moetode yang berbeda yang murni miliknya. Para peneliti kualitatif memanfaatkan semiotika, analisis naratif, isi, wacana, arsip, dan fenomenis bahkan statistika sekalipun. Mereka juga menggunakan dan mendayagunakan pendekatan, metode, 
dan teknik etnometodologi, fenomenologi, hermeneutika, feminisme, rhizomatika, wawancara, psikoanalisis, kajian-kajian budaya, di samping yang lain (Denzin \& Lincoln, 2000: 4).

Semiotika atau ilmu tanda mengadaikan rangkaian asumsi dan konsep yang memungkinkan kita untuk menganalisis sistem simbol dengan cara sistematis, seluruh tindakan komunikasi antar manusia sesungguhnya merupakan tanda; teks yang harus 'dibaca' terlebih dahulu agar dapat dimengerti maksudnya (Denzin \& Lincoln, 2000: 617).

Semiotika film bekerja melalui struktur bahasa film, estetika, serta fenomenologis gambar audiovisual sebagai ekspresi film yang gabungkan dengan hubungan antar tanda yang termaktub dalam sebuah proses sintagmatik yang besar (The Large Syntagmatic). Perhatian utama semiotika film adalah bagaimana makna dibangkitkan dan disampaikan melalui analisa unsur denotatif film, yang merupakan titik tekan semiotika film. Unsur denotatif ini dapat membangun, mengorganisir dan mengkode -melakukan proses signifikansi- tanda-tanda yang terlihat dalam layar, disinilah sebuah proses pemaknaan terjadi (Metz, 1991:70-72).

Pada bukunya, Film Language: A Semiotics of the Cinema (1974), Metz berpendapat bahwa sinema yang terstruktur seperti bahasa. Mengadopsi model Saussure, Metz membuat perbedaan antara "langue" sistem bahasa, dan "bahasa". Metz (1991:74) berpendapat " the cinema is certainly not a language system (langue.)".Film itu tidak dapat dianggap sebagai terdiri dari "langue," dalam arti memiliki tata bahasa yang ketat dan sintaks setara dengan katakata tertulis atau lisan. Berbeda dengan kata-kata tertulis, unit dasar film adalah shot, yang didalamnya terdapat montage, pergerakan kamera, efek optik, interaksi antara visual dan audio dan masih banyak lagi. Kesemuanya bekerja selalu bermotivasi dan ikonik, bukanlah simbolis atau sewenang-wenang dalam proses signifikansi, karena itu film sarat dengan makna khusus (Metz, 1991:74). Bahasa struktur film kemudian dibagi menjadi delapan pengelompokan, dalam "The Large Syntagmatic Category" : Autonomous Shot, Paralel Syntagma, Bracket Syntagma, Descriptive Syntagma, Alternate Syntagma, Scene, Episodic Sequence dan Ordinary Sequence. (Metz, 1991:145-162). James Monaco ( 1977 ) dalam bukunya Art and Visual Perception, menyarankan dalam pembuatan suatu film, banyak sekali element - element yang penting dalam membuat bagaimana suatu scene dapat menceritakan apa yang sutradara inginkan, dan banyak hal yang menjadi pertimbangan element - element apa saja yang ingin di masukan kedalam film tersebut, antara lain, Set dan Properti , Kostum dan Tata Rias (make-up), Bahasa tubuh dan ekspresi wajah, warna , kamera dan tata cahaya dan Editing , Suara atau yang disebut dengan miss en scene.

\section{Hasil Penelitian dan Pembahasan}

Makna berupa simbol ini diuraikan satu persatu sesuai dengan dialog pada film Bulan Terbelah di Langit Amerikauntuk mengetahui wacana terrorisme yang berada di film ini. Penelitian ini menggunakan pendekatan semiotika visual, dalam semiotika komunikasi visual khususnya pada karya film dan iklan, teks memang tidak hanya berupa gambar/ visual, namun juga terbangun atas hadirnya teks yang berupa bahasa verbal maupun non-verbal yang, adapun kode - kode miss en scene dan miss en shot, ialah alat - alat yang dipergunakan oleh pembuat film untuk 
merubah dan menyesuaikan pembacaan shot yang akan dilakukan yang di mana hal tersebut digabungkan satu sama lain hingga menimbulkan emosi tertenu kepada audience.

Dalam film Bulan Terbelah di Langit Amerika ini, terdapat 48 scene yang menceritakan tentang perjalanan Rangga dan Hanum yang mencoba menyatukan kembali orang - orang yang terbelah karena peristiwa 9 / 11, tetapi dalam hal ini penulis mengambil 16 scene yang penulis yakini terdapat code mengenai representasi terrorisme yang dibentuk melalui oleh Mise En Scene dan Mise En Shot, , sebagiamana yang dikatakan oleh Roland Barthes, leksia adalah, sepotong bagian teks, yang apabila diisolasikan akan berdampak atau memiliki fungsi yang khas bila dibandingkan dengan potongan - potongan teks lain disekitar (Bartes : 1990 ).

Untuk dapat "membaca" muatan khusus, seperti misalnya ideologi dalam sebuah film, maka mau tak mau kita harus memperlakukannya sebagai teks. Namun memperlakukan film sebagai teks tidaklah sesederhana seperti kita membaca literatur yang menggunakan dengan tata-bahasa dan aturan-aturan pembentuk makna yang sudah dirumuskan dengan jelas dan disepakati besama selama puluhan, ratusan, bahkan ribuan tahun lamanya.Dalam "bahasa" filmis tidak ada tata-bahasa yang dirumuskan secara ketat seperti layaknya aturan bahasa (Indonesia, Inggris, Perancis dsb.), dan sebagai pengganti elemen-elemen pembentuk maknanya digunakan gambar-gambar yang bergerak (moving pictures/visual) ditambah dengan suara/ sound/audio (dialog, musik, efek dsb.). Bahasa filmis menciptakan makna (yang ditangkap/ diinterpretasikan oleh penonton) dengan menyusun elemen-elemen yang dimilikinya secara kreatif, lewat rangkaian kode-kode yang dibentuk secara teknis, seperti narrative, editing, type of shot, camera angle, camera movement, lighting, sound effect, yang dalam istilah disebut sebagai cinematic apparatus atau Mise en Scene

Bahasa filmis yang terpenting bukanlah memahami apa yang secara fisikal tersampaikan dilayar - seperti halnya aksara membentuk kata, kata melahirkan kalimat, kalimat menciptakan paragraf, dst.-akan tetapi memahami sistem elemen-elemen pembentuk makna tersebut. Dengan kata lain, kita harus menggeser pengamatan kita bukan lagi kepada "apa" makna yang ingin disampaikan menuju "bagaimana" makna tersebut diciptakan/dibangun dalam "bahasa" film, atau bagaimana Mise En Scene tersebut digunakan.

Peneliti menganalisa representasi terorisme dan menjabarkan setiap scene pada film yang berdasarkan The Large Syntagmatic Category, kedelapan teknik tersebut tidak digunakan semua untuk membedah isi scene dalam film, satu rangkaian shot dapat dianalisis dengan satu atau lebih melalui analisa Metz, ada pun delapan teknik dari Christian Metz :

1. Autonomous Shot (establishing shot, insert) : tahap ini merupakan single shot yang ditambah dengan empat jenis insert. Menampilkan episode dari plot, dengan empat jenis insert yang dimaksud adalah: non diegetic insert, subjective insert, displaced insert dan explanatory insert.

2. Paralel Syntagma: merupakan syntagama non-kronologis yang terdiri dari gabungan dari beberapa shot dengan gambar-gambar kontras. Memiliki jalinan dua atau lebih motif, dengan maksud simbolis. Contoh: gambar kota dengan gambar desa, gambar kaya dengan gambar miskin; menyimbolkan suatu paradoks. 
3. Bracket Syntagma : bagian dari syntagma non-kronologis yang menggabungkan gambar-gambar dengan tema yang senada. Meskipun tidak berurutan, namun berusaha menampilkan serpihan kejadian dalam film.

4. Descriptive Syntagma : merupakan bagian dari syntagma kronologis, yang mengurutkan peristiwa dalam satu screen atau setting secara langsung. Menjelaskan secara deskriptif pesan yang terangkai secara langsung. Menghubungkan fakta yang ditemukan di layar atau dengan kata lain menampilkan pesan yang terangkai secara langsung dalam level denotatif (ditampilkan di layar).

5. Alternate Syntagma : peristiwa kronologis yang terjadi dalam dua shot secara bergantian dan berhubungan. Menyatukan shot-shot yang berbeda, namun memiliki satu kesamaan dan disajikan secara simultan.

6. Scene : secara kronologis dan kontinyu menampilkan adegan-adegan spesifik atau khusus yang dapat membentuk kepribadian tokoh. Dapat berupa setting tempat, peristiwa, moment atau aksi. Bersifat kontiyu tanpa ada break/jeda dan pada akhirnya berakhir dalam satu shot.

7. Episodic Sequence : shot yang dalam penyajiannya diskontinyu atau memiliki lompatan, namun cenderung konstan danmasih membicarakan hal/tujuan yang sama.

8. Ordinary Sequence : shot yang lompatannya terkesan tidak teratur, tidak memiliki tema/tujuan yang sama. Tetapi berada pada setting yang sama. Perpindahan/break menandakan kebalikannya, dan tidak terduga.

Film ada sebuah bentuk media komunikasi, di mana semua bentuk komunikasi manusia melibat simbol - simbol, dan kita dapat memahami artinya dengan jelas jika kita telah memiliki ide atau gagasan yang berasosiasi atau yang sudah dimasukan kedalam simbol tersebut. Hal - hal yang memiliki arti simbolis tak terhitung dalam film Bulan Terbelah di Langit Amerika, baik itu setting, make up, dialog, serta gerakan / ekpressi yang dimainkan oleh seorang aktor, dalam kebanyakan film tokoh - tokoh dalam film sering dipergunakan secara simbolik, dan begitu juga tokoh menjadi simbolik, maka konflik yang terlibat dalam perjalanan mereka juga menjadi simbolik dalam film, karena itu simbol adalah sesuatu yang kongkrit, yang mewakili atau melambangkan suatu yang kompleks, karenanya suatu simbol - simbol dalam film di susun melalui sebuah editing dengan melalui montage - montage yang dibangun oleh seorang editor kedalam filmnya, sehingga tatanan simbol - simbol yang disimbolkan mudah untuk di pahami oleh penonton.

Hasil dari penelitian ini dapat diperoleh suatu gambaran mengenai kepribadian setiap tokoh dalam film, melalui tiga sistem dalam struktur kepribadian Freud yaitu id, ego, dan superego. Dinamika antara id, ego, dan superego terjadi dalam setiap konflik internal dan eksternal pada tokoh. Konflik atau pertentangan yang terjadi pada film ini , adalah pertarungan antara Super Ego dari Hanum, yang menggerakan cerita pada film ini dengan tokoh - tokoh yang mencoba melawan Super Ego Hanum melalui Ego yang dimiliki oleh karakter lain. 


\section{Sarah Hussein}

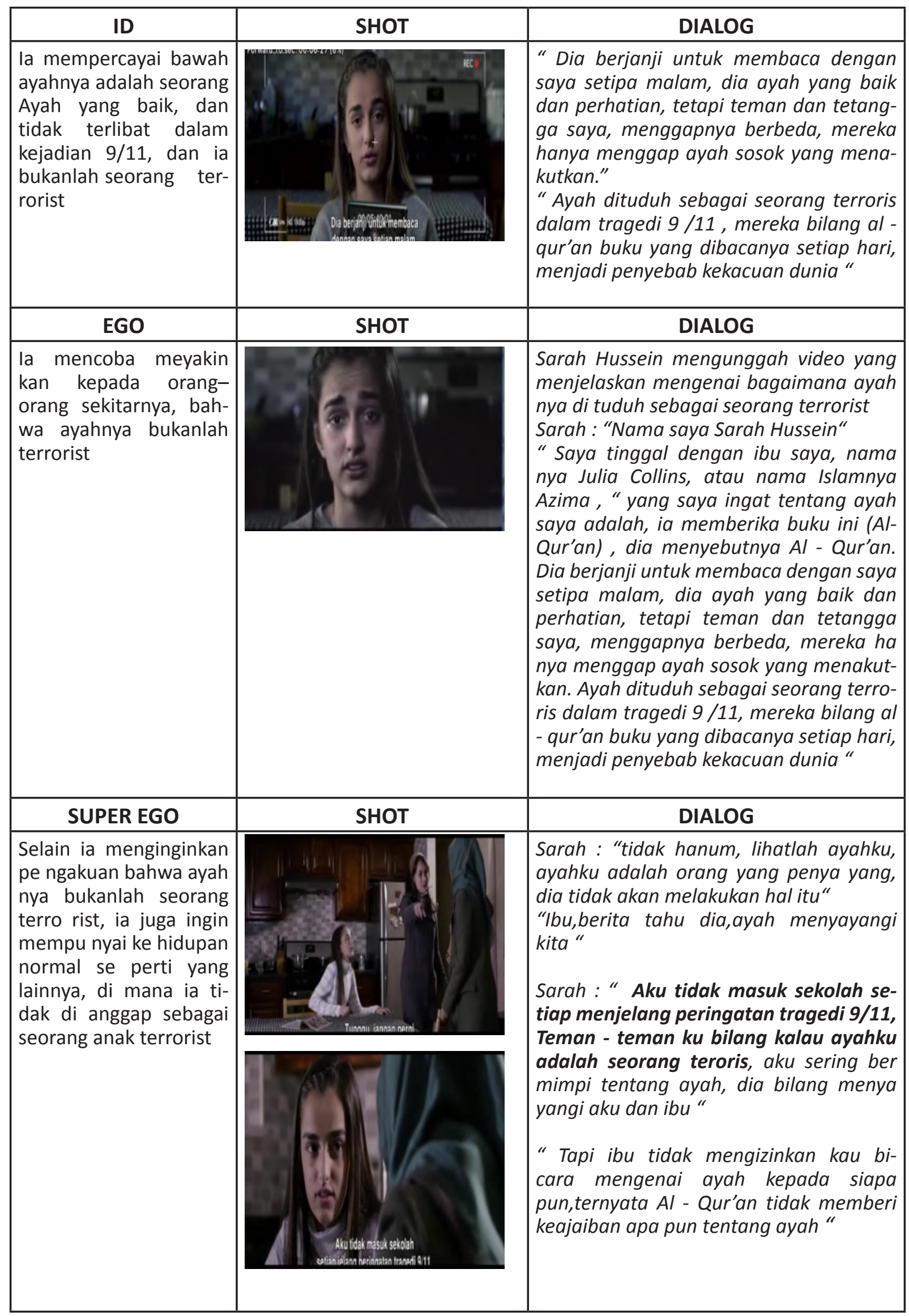


Sarah Hussein, adalah anak dari Hussein dan Azima, memiliki darah campuran Amerika dan arab, awalnya ia hanya seorang anak kecil biasa yang biasa bermain dengan teman temannya, tetapi setelah peristiwa 9/11, teman - teman sebayanya menuduh ayahnya lah yang menjadi terorrist dari peristiwa tersebut, sehingga ia mengalami tekanan dalam kehidupannya, membuat Sarah enggan untuk sekolah ketika ia mendekati perayaan peristwa 9/11, Sarah Hussein melakukan pertahanan mekanisme ego nya, ketika ayahnya dianggap sebagai seorang terrorist, karenanya ia melakukan projeksi kepada dirinya, dengan mencoba meyakinkan orang - orang sekitarnya mengenai bagaimana keberadaan dari ayahnya , dan mencoba memberikan pandangannya kepada orang lain, bahwa ayahnya adalah seorang ayah yang baik serta bukan lah terrorist, dan ia telah memberikan Sarah Al- Qur'an di mana ia mempercayai bahwa dengan Al- Qur'an dapat menenangkannya, tetapi orang - orang sekitarnya, menggapnya sebagai sebuah buku yang berbahaya, karena bisa menebarkan sebuah kebencian, Sarah Hussein pun tidak diterima di kalangan sekitarnya, karena ia dirasa sebagai anak Terrorist, sehingga membuat ia menjadi seorang yang tertutup, ini adalah sebuah bentuk dari mekanisme pertahanan ego Sarah, sehingga membuat ia enggan untuk bisa bergaul dengan teman - temannya, dan membuat ia tidak masuk sekolah menjelang hari peringatan 9/11, karena teman - temannya menyebut ayahnya seorang terrorist.

\section{Azima Hussein / Julia Collins}

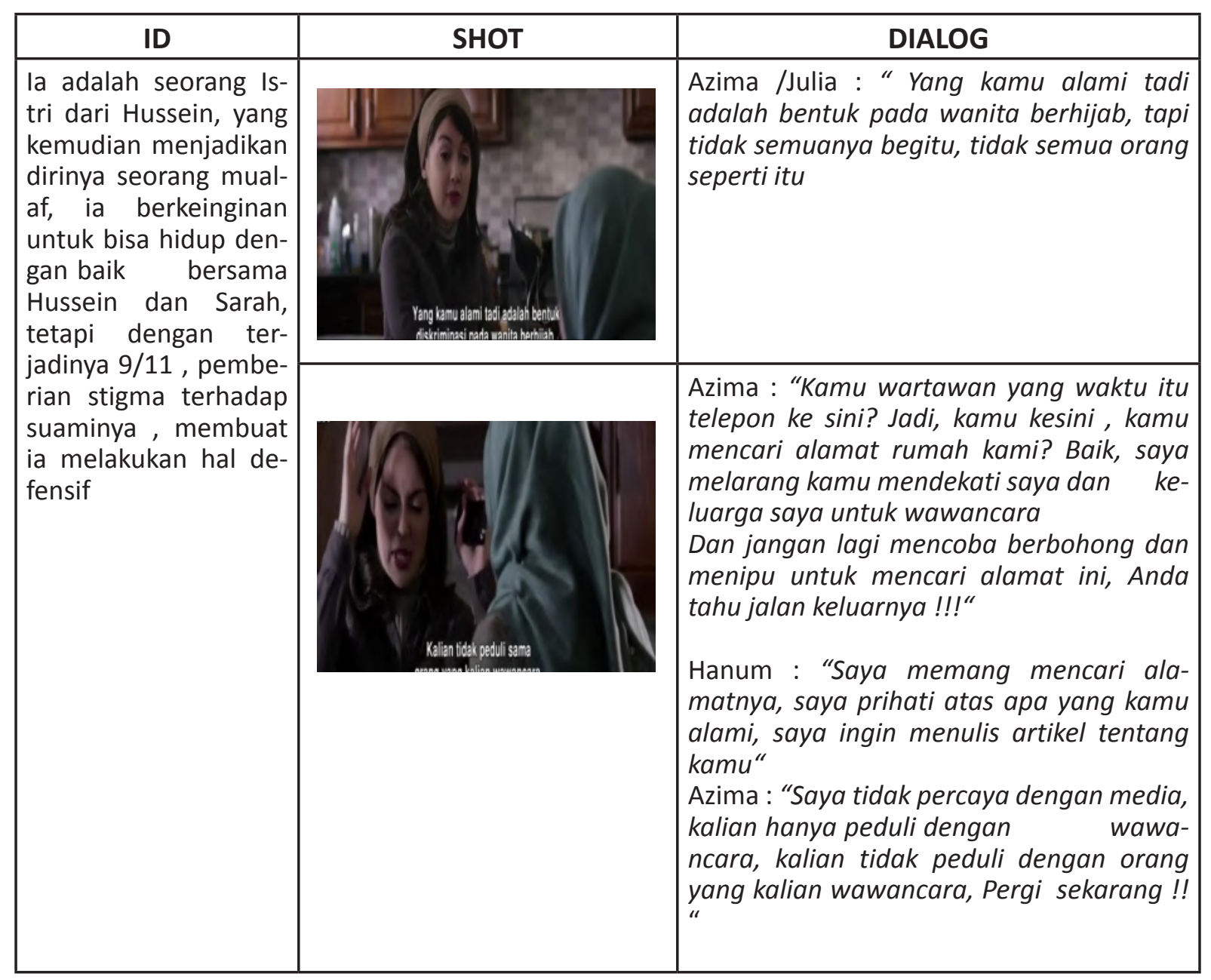




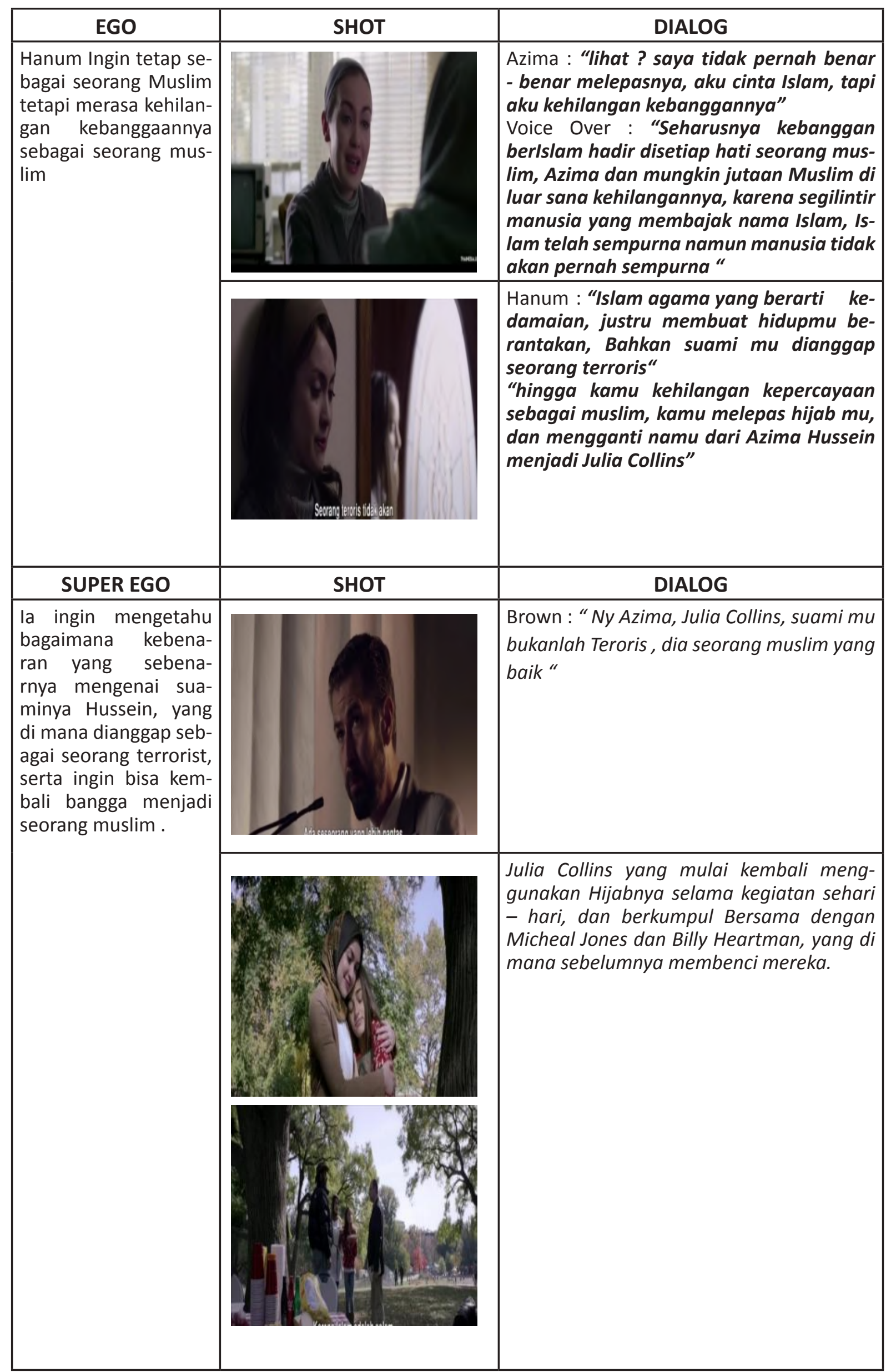


Azima / Sarah Collins, ialah seorang perempuan yang bekerja sebagai pemandu wisata di New York, yang kemudian ia menikah dengan seorang lelaki muslim bernama Hussein, dan menjadikan ia sebagai mualaf, tetapi setelah 9 /11 ia melepas jilbab yang ia gunakan, dan kehilangan kebanggaan dirinya sebagai seorang muslim.Azima Hussein adalah seorang istri yang memiliki kehidupan yang baik, di mana ia mempunyai seorang suami yang menyayangi keluarganya dengan baik, serta bertanggung jawab, tetapi ketika 9/11 terjadi suaminya bertepatan berada di Gedung WTC, dan hal tersebut mengubah kehidupannya, kini ia mengalami penekanan dari orang - orang sekitarnya bahwa suaminya adalah seorang pelaku dari 9/ 11 dan dianggap terrorist, hal tersebut merupakan konflik internal yang dialami oleh Azima, ia mencintai suaminya tetapi ia juga tidak bisa menyangkal bahwa suaminya mungkin saja seorang pelaku dari terjadinya 9/11, dorongan dari orang - orang sekitar yang terus menerus kepada Azima menjadikan dirinya mengalami kecemasan, sehingga secara tidak langsung ia melakukan pertahanan terhadap ego, hingga akhirnya ia melakukan projeksi kepada dirinya serta Sarah, setelah kejadian 9/11 banyak awak media yang melakukan wawancara kepadanya, tetapi hasil dari wawancara tersebut malah menyudutkan keluarganya, sehingga ia sangat skeptis kepada awak media, dengan tekanan yang ia alami hanya berdua bersama dengan Sarah, ia pun memutuskan untuk tidak kembali menggunakan Hijab, karena ketika ia menggunakan Hijab, orang - orang sekitarnya menggap bahwa ia adalah seorang terrorist, ini adalah bentuk pertahanan ego berupa Pembentuan Reaksi , di mana mengganti sikap dan tingkah laku dengan sikap dan tingkah laku yang berlawanan, Azima pun kembali menggunakan nama sebelum ia menikah dengan Hussein yaitu Sarah Collins, lalu ia melakukan Rasionalisasi, di mana ia menciptakan kepalsuan yang ia lakukan adalah sebagian upaya pembenaran tingkah lakunya yang tidak bisa diterima oleh dirinya

\section{HANUM}

\begin{tabular}{|c|c|c|}
\hline ID & SHOT & DIALOG \\
\hline \multirow[t]{2}{*}{$\begin{array}{l}\text { la mempercayai bah- } \\
\text { wa selama ini ang- } \\
\text { gapan orang - orang } \\
\text { mengenai Islam yang } \\
\text { seharusnya bertang- } \\
\text { gung jawab terhadap } \\
\text { peristiwa } 9 / 11 \text { adalah } \\
\text { salah }\end{array}$} & & $\begin{array}{l}\text { Hanum : "Gertrude, sejak kejadian itu, du- } \\
\text { nia muslim terpinggirkan diusir dari kehidu- } \\
\text { pan sosial mereka, karena keyakina mereka, } \\
\text { hidup mereka dipersulit banyak orang" } \\
\text { Gertrude: "Maksud mu itu memang bagus, } \\
\text { tapi faktanya Hanum. Terrorist itu adalah } \\
\text { Muslim" }\end{array}$ \\
\hline & & $\begin{array}{l}\text { Hanum : "ini monument kesedihan", } \\
\text { "Tempat banyak jatuhnya korban akibat } \\
\text { tragedi kemanusiaan" } \\
\text { Rangga : "Terlalu banyak korbannya" } \\
\text { "Num di antaranya ada yang muslim" }\end{array}$ \\
\hline
\end{tabular}




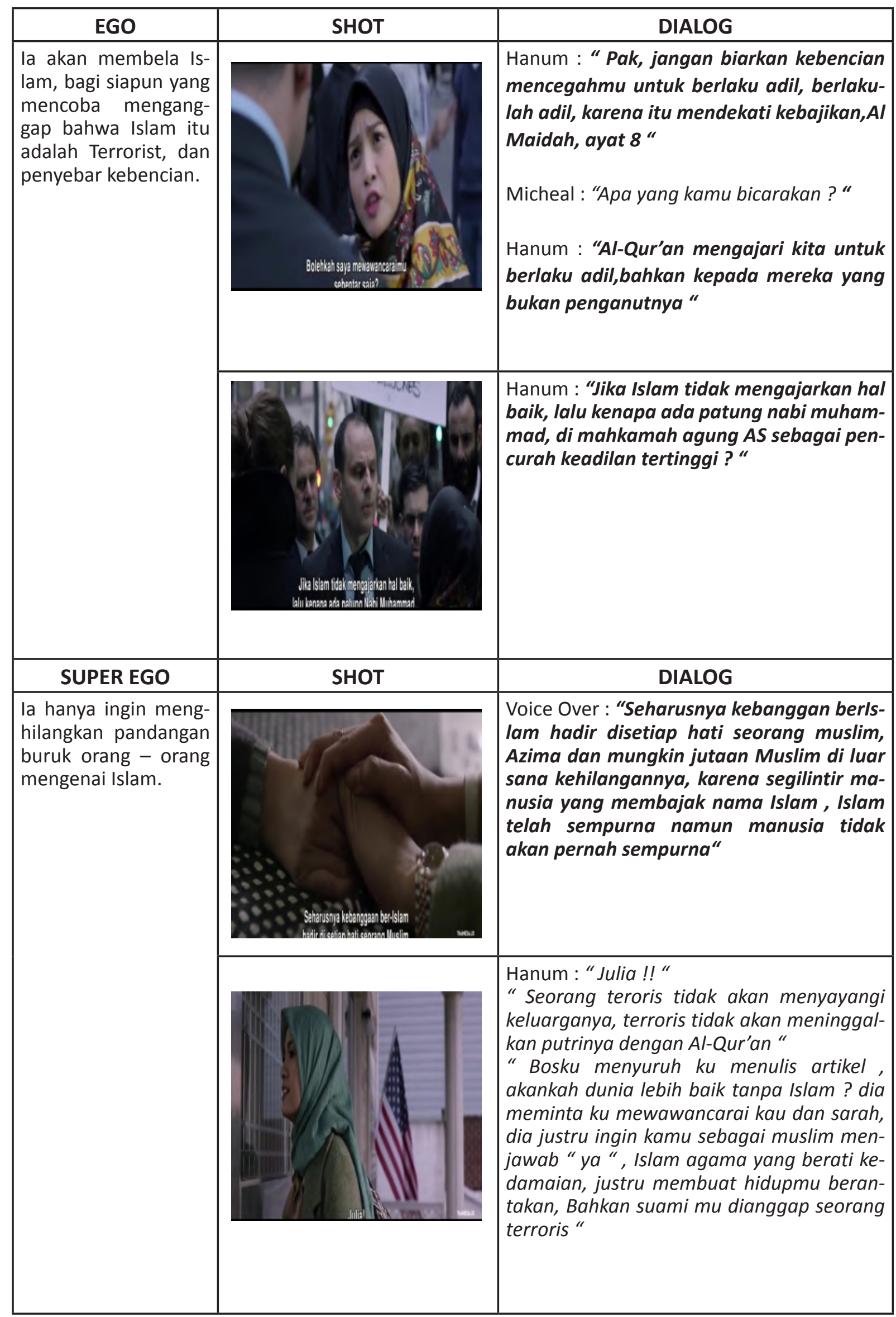




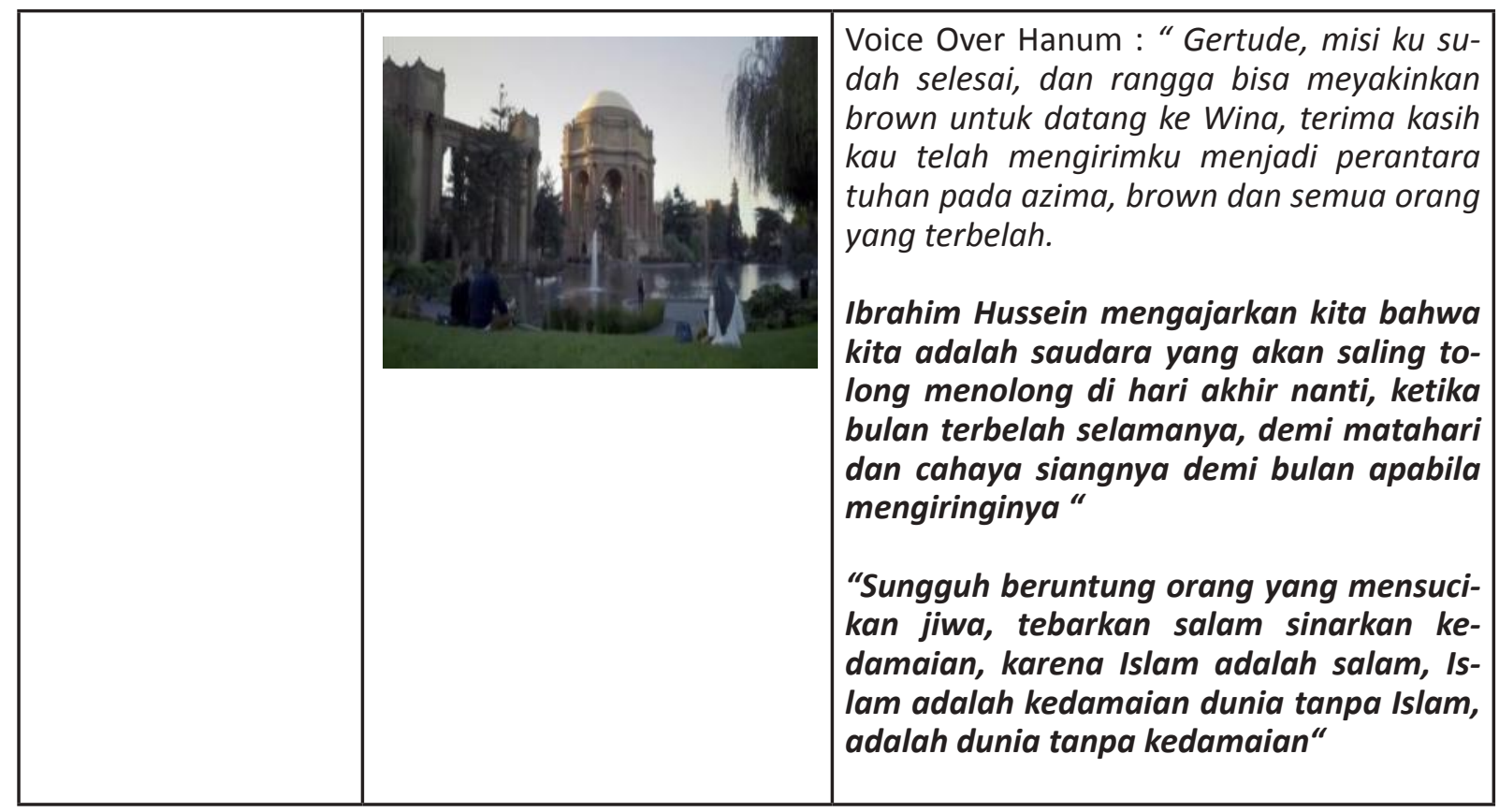

Hanum adalah seorang jurnalis yang tengah di tugaskan oleh atasannya yang bernama Gertrude, ia tengah diminta untuk menulis sebuah artikel mengenai bagaimana dunia tanpa Islam, di mana Getrude meminta kepada Hanum untuk bisa memwawancarai Sarah dan Azima, di mana kedua orang tersebut di curigai sebagai istri dan anak dari pelaku terjadinya 9/11, yang bernama Hussein, di mana ketika peristiwa tersebut Hussein berada di 9/11 dan di duga sebagai pelaku dari kejadian tersebut, sesampainya disana, Hanum menemui banyak tantangan yang mengancam ego dirinya, mulai dari seorang Micheal Jones, Billy Heartman, serta Azima dan Sarah sendiri, ketika ia bertemu dengan Micheal Jones, ia dihadapkan dengan seseorang yang memiliki stigma buruk kepada mereka yang beragama muslim, Jones menganggap bahwa yang seharusnya bertanggung jawab atas kejadian 9/11 adalah mereka para Muslim, teteapi Hanum berpendapat lain, bahwa "Jangan biarkan kebencian mencegahmu untuk berlaku adil, berlakulah adil, karena itu mendekati kebajikan,Al Maidah, ayat 8 ," lalu ia dihadapkan pada seseorang yang lelaki yang telah kehilangan keluarganya di 9/11 yang merupakan tetangga dari Sarah yang bernama Billy Heartman, ketika ia tengah menanyakan alamat dari Azima, Hanum datang kerumah Billy, tetapi ketika Billy membukakan pintu Billy malah menyerang hanum dengan sebuah intimadsi, karena hanum menggunakan hijab , di mana hijab adalah salah satu pakaian yang dikenakan oleh para muslim, billy yang melihat tersebut langsung mengatakan kepada Hanum , " : " Apa ini yang diajarkan Al-Qur'an ? katakan padaku Hanum, Apakah AlQur'an mengajarkan membunuh orang yang berbeda dari kalian ? "Apa kau diajarkan untuk membunuh putraku dan ribuan orang di tragedi itu?

Hanum pun akhirnya dipertemukan oleh Azima dan Sarah, tetapi mereka sudah benci dengan akan adanya seorang wartawan ataupun media, baginya media hanya menyudutkan mereka dengan berita-beritanya tanpa memperdulikan narasumber yang mereka wawancarai,

Hanum pun di usir dari rumah oleh Sarah dan Azima, meyakinkan mereka dengan mengatakan bahwa, " Julia !! " , "Seorang teroris tidak akan menyayangi keluarganya, terroris tidak akan meninggalkan putrinya dengan Al-Qur'an ", "Bosku menyuruh ku menulis artikel 
, akankah dunia lebih baik tanpa Islam ? dia meminta ku mewawancarai kau dan sarah, dia justru ingin kamu sebagai muslim menjawab "ya " , Islam agama yang berati kedamaian, justru membuat hidupmu berantakan, Bahkan suami mu dianggap seorang terroris ".

Dalam beberapa scene, Hanum pun digunakan sebagai Voice Over, karena berfungsi melebihi peranannya sebagai sesuatu yang bersifat saling mengisi dan melayani serta menduduki fungsi " bercerita "yang penting, dengan demikian seorang sutradara mengutarakan hal - hal yang tidak dapat diutarakan melalui saluran gambar. Hal ini khusus kita temui pada hal - hal di mana keadaan fikiran seorang tokoh mengalami perbahan cepat dan radikat yang tidak dapat diutrakan melalui gambar - gambar yang memadai, secara keseluruhan tokoh Hanum mengalami mekanisme pertahanan ego, yang di sebut dengan Represi, di mana Hanum merasa bahwa apa yang dialaminya tidak sesuai dengan $I d$, hingga ahkirnya membuat ia membuat penekanan dorongan - dorongan ke alam tak sadarnya untuk melindungi dirinya.

\section{MICHEAL JONES}

\begin{tabular}{|c|c|c|}
\hline ID & SHOT & DIALOG \\
\hline $\begin{array}{l}\text { la mempercayai bahwa } \\
\text { terjadinya } 9 / 11 \text { karena } \\
\text { Terrorist, dan Terorrist } \\
\text { adalah seorang Muslim }\end{array}$ & & $\begin{array}{l}\text { Micheal : "Jangan menceramahi saya, } \\
\text { Muslim menyebar pembunuhan dan } \\
\text { kehancuran di seluruh dunia, mereka } \\
\text { membuat hidup saya sia - sia, mereka } \\
\text { merenggut istri saya, Anna!!" }\end{array}$ \\
\hline EGO & SHOT & DIALOG \\
\hline $\begin{array}{l}\text { Dengan meninggalnya } \\
\text { Anna yang merupakan } \\
\text { istri dari Micheal Jones, } \\
\text { membuat ia menjadi se- } \\
\text { seorang yang membenci } \\
\text { muslim, sehingga ia me- } \\
\text { nolak muslim untuk bera- } \\
\text { da di New York, Amerika. }\end{array}$ & & $\begin{array}{l}\text { Micheal : "Ya, besok kami akan ber- } \\
\text { baris menentang Masjid Ground Zero, } \\
\text { beraninya para muslim membangun } \\
\text { masjid mereka di lokasi ground zero? } \\
\text { "Mereka menghina kita!! mereka me- } \\
\text { ludahi kubran orang - orang tercinta } \\
\text { kita!" }\end{array}$ \\
\hline SUPER EGO & SHOT & DIALOG \\
\hline $\begin{array}{l}\text { la hanya ingin membalas- } \\
\text { kan dendam atas mening- } \\
\text { gal istrinya yang menjadi } \\
\text { korban atas terjadinya } \\
9 / 11 \text {, tetapi ketika Phili- } \\
\text { pus Brown memberikan } \\
\text { pidato pada "Hero of The } \\
\text { Year ", mengubah pandan- } \\
\text { gannya mengenai Muslim }\end{array}$ & & $\begin{array}{l}\text { Brown : "Bertahanlah Anna, kamu ha- } \\
\text { rus bertahan, ayoo!! " } \\
\text { Anna: "Kumohon, lepaskan aku" } \\
\text { Hussein : "Tidak!! Kuatkan Keyaki- } \\
\text { nanmu, ingatlah suami, keluargamu !! } \\
\text { Anna!! " } \\
\text { Anna : "Aku ingin mati! Lepaskan aku } \\
\text { !! " } \\
\text { Brown: "dan Micheal Jones, saya me- } \\
\text { lihatmu di tv beberapa waktu lalu, } \\
\text { saya ingin menghubungimu dan mem- } \\
\text { beritahumu sesuatu, saya menyaksikan } \\
\text { Mr.Hussein berusaha menyelamatkan } \\
\text { istrimu Anna, dan mempertaruhkan } \\
\text { nyawanya sendiri" }\end{array}$ \\
\hline
\end{tabular}


Micheal Jones adalah seorang pemimpin dari gerakan orang-orang yang menolak akan pembangunan masjid di Ground Zero, Jones melakukan hal tersebut karena ia kehilangan istrinya Anna di Tragedi 9 /11, Jones merasa bahwa pelaku dari kejadian tersebut adalah orangorang muslim, hingga akhirnya ia memunculkan Rasionalisasi, di mana ia mengeneralisasikan orang-orang muslim adalah seorang terrorist, dan muslim adalah menyebar pembunuhan dan kehancuran di seluruh dunia, Jones merasa bahwa apa yang ia fikirkan ini tidak hanya sendiri, hingga akhirnya ia membuat sebuah gerakan demo dan dirinya sebagai pemimpin dari kegiatan tersebut, hal ini disebut dengan Identifikasi, di mana ia memperkuat dirinya dengan membuat suatu persekutuan nyata atau maya dengan orang lain, dengan adanya persekutuan yang dimiliki Jones, kini Jones dengan mudah untuk menggiring pemikiran orang lain dan menguatkan pemikiran orang lain bahwa pembangunan masjid di Ground Zero, adalah salah satu bentuk pelecehan kepada mereka yang telah meninggal di 9/11, dan muslim tidak pantas mendapatkan pembangunan masjid di Ground Zero, apa yang Jones lakukan ini adalah bentuk dari Projeksi, di mana ia mengalihkan pikiran perasaan serta dorongan diri sendirinya kepada orang lain, di mana ia mendorong dan menghasut orang-orang sekitarnya untuk sama-sama menolak pembangunan masjid di Ground Zero

\section{BILLY HARTMAN}

\begin{tabular}{|c|c|c|}
\hline ID & SHOT & DIALOG \\
\hline $\begin{array}{l}\text { Meninggalnya ke- } \\
\text { luarga Billy di } 9 / 11 \\
\text { membuat ia mem- } \\
\text { benci muslim, dan } \\
\text { menuduh muslim se- } \\
\text { bagai pelaku terrorist }\end{array}$ & & $\begin{array}{l}\text { Billy : "Apa ini yang diajarkan Al-Qur'an? } \\
\text { katakan padaku Hanum, Apakah Al- } \\
\text { Qur'an mengajarkan membunuh orang } \\
\text { yang berbeda dari kalian? } \\
\text { "Apa kau diajarkan untuk membunuh } \\
\text { putraku dan ribuan orang di tragedi itu?" }\end{array}$ \\
\hline EGO & SHOT & DIALOG \\
\hline $\begin{array}{l}\text { Dengan munculnya } \\
\text { kebencian Billy ter- } \\
\text { hadap umat muslim, } \\
\text { menjadikan dirinya } \\
\text { memberikan jarak } \\
\text { kepada mereka yang } \\
\text { beragama Islam. }\end{array}$ & & $\begin{array}{l}\text { Azima : "Hai Billy, kamu tidak suka kuenya } \\
\text { ? Sarah membuatnya khusus untukmu" } \\
\text { Billy: "Kue ini tidak mengembalikan } \\
\text { keluarga ku, kue ini tidak ada artinya bagi } \\
\text { ku, jadi tolong jangan memohon dariku } \\
\text { lagi" }\end{array}$ \\
\hline SUPER EGO & 1OT & DIALOG \\
\hline $\begin{array}{l}\text { Billy hanya ingin bisa } \\
\text { mempunyai sebuah } \\
\text { keluarga yang leng- } \\
\text { kap. }\end{array}$ & & $\begin{array}{l}\text { Billy : Julia, Terima Kasih atas kuenya, kue } \\
\text { yang indah sekali. } \\
\text { Julia / Azima : sama - sama }\end{array}$ \\
\hline
\end{tabular}


Billy Heartman adalah seorang pria paruh baya, yang bertetangga dengan Azima dan Sarah, tetapi dengan meninggalnya keluarganya di kejadian 9/11, ia menggap bahwa orang - orang muslim yang harus bertanggung jawab dengan meninggalnya putranya dan ribuan orang lainnya, dengan hal tersebut menjadikan dirinya melakukan pertahanan mekanisme egonya berupa rasionalisasi, di mana ia mengeneralisasikan orang - orang muslim adalah seorang terrorist, serta merekalah yang harus bertanggung jawab dengan kejadian 9/11, dengan kehilangan putranya, ia melakukan pembentukan reaksi, di mana ketika ia melihat seseorang yang menggunakan hijab ataupun mereka yang menggunakan pakaian bercirikan orang muslim, hal tersebut dijelaskan pada shot diatas di mana ketika Azima menjelaskan apa yang terjadi apa Hanum, adalah bentuk perilaku pada wanita berhijab, ketika Hanum mencoba menanyakan alamat rumah Sarah kepada Billy.

\section{PHILIPUS BROWN}

\begin{tabular}{|c|c|c|}
\hline ID & SHOT & DIALOG \\
\hline $\begin{array}{llr}\text { Seorang Pengusaha } \\
\text { yang sukses yang } \\
\text { menghalalkan segala } \\
\text { cara. }\end{array}$ & & $\begin{array}{l}\text { Hussein: "Tuan Brown, jika Morgan Stanway } \\
\text { berpartisipasi dalam proyek ini, saya yakin ini } \\
\text { akan mendorong nama besar, dan citra peru- } \\
\text { sahaan ini" } \\
\text { Brown : "Sahabatku, kamu gila!!" } \\
\text { "Ini membutuhkan banyak uang, dan nama } \\
\text { baik perusahaan saya, dan saya juga tidak } \\
\text { peduli pada anak-anak ini" }\end{array}$ \\
\hline EGO & SHOT & DIALOG \\
\hline $\begin{array}{l}\text { la tidak memperdu- } \\
\text { likan segala sesuatu } \\
\text { urusan yang tidak } \\
\text { menguntungkan bag- } \\
\text { inya dan perusahaan- } \\
\text { nya }\end{array}$ & & $\begin{array}{l}\text { Hussein : "Pak, dalam agama saya, kami yakin } \\
\text { ada kekuatan dalam memberi,berdasarkan } \\
\text { ketulusan dan pengabdian kami pada Tuhan" } \\
\text { Brown : "Ini keyakinan mu, bukan keyakinan } \\
\text { ku" } \\
\text { "Keyakinanmu itu konyol dan bodoh, dalam } \\
\text { hidup, hadiah terbesar adalah dengan bekerja } \\
\text { keras pada sesuatu yang pantas diusahakan, } \\
\text { ini tidak pantas di usahakan" }\end{array}$ \\
\hline SUPER EGO & SHOT & DIALOG \\
\hline $\begin{array}{l}\text { Setelah ia diberikan } \\
\text { kesempatan kedua } \\
\text { oleh lbrahim Hussein, } \\
\text { kehidupannya men- } \\
\text { jadi berubah drastis, } \\
\text { di mana ia menjadi } \\
\text { seseorang yang der- } \\
\text { mawan }\end{array}$ & & $\begin{array}{l}\text { Brown : " Tuan Ibrahim Hussein adalah } \\
\text { seorang muslim, namun yang penting, dia } \\
\text { adalah manusaia yang luar biasa. } \\
\text { Saya ditanya sesuatu yang menarik, pertan- } \\
\text { yaan adalah seperti ini, akankah dunia lebih } \\
\text { baik tanpa Islam ? Kebanyakan muslim terus } \\
\text { memberi disepanjang tahun, Islam mengajar- } \\
\text { kan Muslim untuk baik kepada sesamanya. } \\
\text { Islam adalah agama yang penuh dengan ke- } \\
\text { baikan dan perdamaian, jadi jika anda ber- } \\
\text { tanya kepada saya, akankah dunia lebih baik } \\
\text { tanpa Islam? } \\
\text { Maka jawaban saya sudah tentu tidak, dunia } \\
\text { akan lebih dengan adanya Islam }\end{array}$ \\
\hline
\end{tabular}




\section{Simpulan}

Representasi teroris pada film Bulan Terbelah di Langit Amerika ditunjukan dalam bentuk: (1) Teror, direpresentasikan berupa penekanan akan Super Ego pada karakter Hanum, Sarah, dan Azima, dimana pada film ini Pembentukan Reaksi yang dilakukan oleh Micheal Jones, Billy, serta lingkungan sekitar merupakan penggantian sikap dan tingkah laku dengan sikap dan tingkah laku yang berlawanan, Rizal Mantovani mencoba menggaambarkan mengenai bagaimana terror yang diciptakan oleh public menjadikan Agama Islam di Amerika mengalami perubahan makna yang digambarkan dengan karakter Micheal Jones, dan Billy Heartman, dimana kedua tokoh tersebut memiliki ego akan menghilangkan agama Islam di Amerika, karenanya segala tingkah dan laku pada karakter tersebut mencoba menghilangkan Super Ego yang dimiliki oleh Azima, Hanum, dan Sarah, yang dimana mereka ingin bangga menjadi seorang umat Islam, dan ingin menghilangkan fikiran orang lain mengenai Islam adalah agama yang menyebar kebencian. (2) Intimidasi, direpresentasikan melalui media - media menyorot karakter Sarah dan Azima, sehingga menciptakan trauma psikologis kepada mereka, terlihat kekerasan simbolik yang terlihat dari narasi (verbal) dan bahasa tubuh (non verbal), Hanum digambarkan sebagai sebagi seorang sosok tokoh pahlawan yang mencoba untuk melawan intimidasi dari bangsa barat, dimana ia selalu membantah segala argument yang dikeluarkan dari tokoh antagonis dalam film ini, Hanum mencoba memberikan penjelasan kepada mereka (anatagonis) bahwa yang mereka lakukan selama ini adalah sebuah kesalahpahaman, bahwa terror yang terjadi pada 9 / 11, bukan lah Islam tetapi terrorist yang mengatasnamakan Islam. (3) Pengakuan Bangsa Barat, direpresentasikan melalui karakter Philipus Brown, Brown pada film tidaklah begitu diberikan porsi banyak untuk penampilannya, tetapi pada saat terakhir, Brown medapat sebuah Scene penting, dimana Brown memberikan sebuah penjelasan bahwa dunia akan lebih dengan adanya Islam, pernyataan Brown tersebut adalah dorongan Id nya yang akhirnya membuat keseluruhan karakter yang dahulunya membenci Islam menjadi karakter yang menyukai Islam, karakter Brown ini sendiri awalnya digambarkan sebagai karakter yang tamak dan memiliki ambisi yang kuat, tetapi setelah ia tolong oleh Ibrahim Hussein, membuat Id dari Brown berubah total, ia menjadi karakter yang ramah, serta mau membantu sesama, sehingga karakter dari Brown ini adalah bentuk dari representasi akan Islam butuh Pengakuan dari bangsat barat, bahwa dunia membutuhkan Islam.

\section{Daftar Pustaka}

Hall, S. (2002). Representation and the Media. The Media Book.

Metz. Christiam.(1982). The Imaginary Signifier Psychoanalysis and The Cinema. Bloomington and Indianapolis: Indiana University Press

Stam, Robert, Robert Burgoyne and Sandy Flitterman-Lewis. (1992). New Vocabularies In Film Semiotics Structuralism, post-structuralism and beyond. New York : Routledge

Denzin, N. K., \& Lincoln, Y. S. (2000). Handbook of qualitative research. Handbook of Qualitative Research (Vol. 2nd).

Franco, E. P. C., Lucia, V., \& Araújo, S. (2003). Reading Television. The Translator (Vol. 9). 
Cole, B. (2006). Conflict, Terrorism and the Media in Asia. Terrorism, 145.

Norris, P., Kern, M., \& Just, M. R. (2003). Framing Terrorism: The News Media, the Government, and the Public.

Fiske, J. (1990). Introduction To Communication Studies, Second edition.

Eisenstein, S. (1947). The Film Sense. Film form [and]: The film sense; two complete and unabridged works. USA : Meridian Books

Monaco,James. ( 1977 ). Cara Menghayati Sebuah Film.Terjemahan Asrul Rani. Jakarta : Yayasan Citra

Ali.Matius.( 2010 ). Psikologi Film : membaca Film lewat Psikoanalisis Lacan - Zizek. Jakarta :Fakultas Film dan Televisi IKJ

Budiman,Kriss. (2011). Semiotika Visual : Konsep, Isu, dan Problem Ikonitas. Yogyakara : Jalan Sutra.

Boggs. Josep. The Art Of Watching Film.Terjemahan Terjemahan Asrul Rani.Jakarta : Yayasan Citra

Mascelli, Joseph V. The Five C's Of Cinematography.Terjemahan H.Misbach Yuan Biran Jakarta :Fakultas Film dan Televisi IKJ

Mitry, Jean. (2000). Semiotics and the Analysis of Film. Great Britain : The Athlone Press

Rabiger, Micheal \& Mick Hurbis. (2013). Directing : Film Techniques and Aesthetics. Burlington : MA

Stam, R. (2000). Film Theory: An Introduction. In Literarure and Film: A Guide to the Theory and Practice of Film Adaptation.USA : Blackwell Publisher Inc.

Boggs, J. M., \& Petrie, D. W. (2008). The Art of Watching Films Structure.

Dancyger, Ken ( 2002 ). The Technique Of Film and Video Editing Third Edtion. Burlington : MA

\section{Jurnal}

Diskriminasi Perempuan Muslim dalam Implementasi Civil Right Act 1964 di Amerika Serikat (Discrimination toward Moslem Women in the Implementation of Civil Right Act 1964 in the United States of America 